\title{
EFFECT OF MERGER ON BANKING SECTOR- A CASE STUDY OF SBI
}

\author{
*Dr. Nilmani Tripathi \\ Assistant Professor AMITY University
}

\author{
**Nidhi Ahuja \\ Research Scholar AMITY University
}

Article DOI: https://doi.org/10.36713/epra4071

\begin{abstract}
Over the last decade Indian banking industry had gone to a rapid changes. Global slow down had forced government to take corrective measures to boost up the financial market of economy. Accordingly the government approved the merger of SBI and its associates in 2017. The present paper tries to find out the reasons behind mergers and shows its effect on profitability and productivity of SBI. Analysis shows although the productivity of the bank had decreased after the merger, its profitability had improved.
\end{abstract}

\section{INTRODUCTION}

In today's global market, organisations have greatly increased in size and complexity to face rapidly changing business environment. It has been realised globally that merger and acquisitions is one of the healthiest way to gain competitive advantage both domestically and internationally. Merger is when two companies of similar size and nature combine to form a new company. The identity of both the companies is lost and a new company emerges in its place whereas, acquisition is when one company takeover the business of another company. In this the identity of purchasing company remains whereas other company's identity is lost and no new company is formed. Merger and Acquisitions can take place by purchasing of assets; by purchasing shares; by exchange of shares for assets; by exchanging shares for shares. Whether the purchase of one company by another is a Merger or Acquisition depends completely on the methodology adopted for its execution. If the purchase is done with the consent of board of directors then it is a friendly takeover or we can say that it is a merger and if it is without the consent of board of directors then it is forced takeover or acquisition. Other major types of Merger and Acquisition are Horizontal merger that takes place between two companies performing similar types of activities for example- merger of TOMCO with Hindustan lever and Corus with Tata Steel. Vertical Merger takes place when firms in successive stages of the same industry are integrated. Vertical merger may be backward, forward or both ways. Merger of Renu Sagar Power Supply with Hindalco and General Chemical Products Ltd. are example of vertical merger. Third, Conglomerate Merger is a merger between firms that are involved in totally unrelated business activities for example- merger of Broke Bond Lipton with Hindustan Lever. Last, Concentric Merger refers to combination of two or more firms which perform similar kind of business and have different line of products for example- Citigroup's acquisition of Travellers Insurance.

\section{BENEFITS OF MERGER AND ACQUISITION}

The basic purpose or benefits of merger and acquisitions are following-

1. Synergy- It is the idea that by combining business activities performance will increase and costs will decrease. It means a business will attempt to merge with another business that has complementary strengths and weaknesses.

2. Growth- Mergers can give the acquiring company an opportunity to grow market share without having to really earn it by doing the work themselves and expand two companies marketing and distribution providing them new business opportunities.

3. Eliminate Competition- Many Mergers \& Acquisitions deals allow the purchasing firm to 
eliminate future competition and gain a larger market share in its product's market.

4. Diversification of risk-Companies go in for mergers to get the benefits of diversification. A company acquires another company dealing in different products and services to reduce the uncertainty of its earnings.

5. Improved Management-For instance, a business with good management and process systems will be useful to a buyer who wants to improve their own.

The benefits mentioned here are just indicative and the list is not exhaustive. Research has proved that organisations have reaped exceptional benefits of mergers. The study indicates a few global Mergers \& Acquisitions in the form of a table put chronologically for almost past 20 years.

Table 1- Merger and Acquisitions (Time Line)

\begin{tabular}{|c|c|c|}
\hline Year & Acquirer Company & Target Company \\
\hline \multirow[t]{6}{*}{1998} & AT\&T Corp & Tele-Communications Inc. \\
\hline & Travellers Group Inc. & Citicorp \\
\hline & British Petroleum Co PLC & Amoco corp \\
\hline & Daimler-Benz AG & Chrysler Corp \\
\hline & SBC Communications Inc. & Ameritech Corp \\
\hline & NationsBank Corp,Charlotte,NC & BankAmerica Corp \\
\hline \multirow[t]{3}{*}{1999} & Vodafone Group PLC & Air Touch Communications Inc. \\
\hline & Vodafone AirTouch PLC & Mannesmann AG \\
\hline & Royal Bank of Scotland Group & National Westminster Bank PLC \\
\hline 2000 & America Online Inc & Time Warner \\
\hline 2002 & Pfizer Inc & Pharmacia Corp \\
\hline \multirow[t]{2}{*}{2004} & Royal Dutch Petroleum Co & Shell Transport \& Trading Co \\
\hline & JPMorgan Chase \& Co & Bank One Corp,Chicago,IL \\
\hline \multirow[t]{3}{*}{2006} & AT\&T Inc. & BellSouth Corp \\
\hline & PSA Corp Ltd & Hutchison Port Holdings Ltd \\
\hline & MTN Group Ltd & Investcom LLC \\
\hline \multirow[t]{2}{*}{2007} & Vodafone Group PLC & Hutchison Essar Ltd \\
\hline & Lafarge SA & OCI Cement Group \\
\hline \multirow[t]{2}{*}{2008} & Teva Pharmaceutical Industries & Barr Pharmaceuticals Inc. \\
\hline & China Unicom Ltd & China Netcom Grp(HK)Corp Ltd \\
\hline \multirow[t]{2}{*}{2009} & HM Treasury & Royal Bank of Scotland Group \\
\hline & Advanced Tech Invest Co LLC & Chartered Semiconductor Mfg. \\
\hline 2010 & Teva Pharmaceutical Industries & Ratiopharm International GmbH \\
\hline 2012 & Glencore International PLC & Xstrata PLC \\
\hline \multirow[t]{2}{*}{2013} & Verizon Communications Inc. & Verizon Wireless Inc \\
\hline & Bank of Tokyo-Mitsubishi UFJ & Bank of Ayudhya PCL \\
\hline 2014 & Investor Group & Sinopec Sales Co Ltd \\
\hline \multirow[t]{4}{*}{2015} & Royal Dutch Shell PLC & BG GroupPlc \\
\hline & Charter Communications Inc & Time Warner Cable Inc \\
\hline & Petrol Complex Pte Ltd & Essar Oil Ltd \\
\hline & Dell Inc. & EMC Corp \\
\hline \multirow[t]{3}{*}{2016} & AT\&T Inc. & Time Warner Inc. \\
\hline & British American Tobacco PLC & Reynolds American Inc. \\
\hline & GE Oil \& Gas & Baker Hughes Inc. \\
\hline
\end{tabular}




\section{MERGERS AND ACQUISITIONS IN INDIAN BANKING SECTOR}

Banking industry plays a very important role in the economic growth of a country. Mergers and Acquisitions have become a positive way for growth in the size of banks which in turn play a significant role in entering the competitive global financial market. Merger and Acquisitions in Indian banking sector started from the year 1969 in which 14 large commercial banks were nationalized and year 1980 witnessed nationalization of 6 more commercial banks.

Table 2: Merger \&Acquisitions in Indian Banking Sector

\begin{tabular}{|l|l|l|}
\hline Year & Acquirer Company & Merged Company \\
\hline 1993 & Punjab National Bank & New Bank of India \\
\hline 1994 & Bank of India & Bank of Karad Ltd. \\
\hline 1995 & State Bank of India & Kashinath State Bank \\
\hline 1996 & Oriental Bank of Commerce & Punjab Co-op Ltd. \\
\hline 1997 & Oriental Bank of Commerce & Bari Doab Bank Ltd. \\
\hline 1999 & Union Bank of India & Sikkim Bank Ltd. \\
\hline & Bank of Baroda & Bareilly Co-op Ltd. \\
\hline 2000 & HDFC Bank Ltd. & Times Bank Ltd. \\
\hline 2001 & ICICI Bank & Bank of Madura \\
\hline 2002 & Bank of Baroda & Banaras State Bank Ltd. \\
\hline & ICICI Bank & ICICI Ltd. \\
\hline 2003 & Punjab National Bank & Nedungadi Bank Ltd. \\
\hline 2004 & Industrial Development Bank of India & IDBI Bank Ltd. \\
\hline & Bank of Baroda & South Gujarat Local Area Bank \\
\hline & Oriental Bank of Commerce & Global Trust Bank \\
\hline 2005 & Bank of Punjab & Centurion Bank \\
\hline 2006 & Federal Bank & Ganesh Bank of Kurandwad \\
\hline & Industrial Development Bank of India & United Western Bank \\
\hline & Centurion Bank of Punjab & Lord Krishna Bank \\
\hline & ICICI Bank & Sangli Bank \\
\hline 2007 & Indian Overseas Bank & Bharat Overseas Bank \\
\hline 2008 & HDFC Bank & Centurion Bank of Punjab \\
\hline 2010 & ICICI Bank & Bank of Rajasthan Ltd. \\
\hline 2014 & Kotak Mahindra Bank & ING Vyasa Bank \\
\hline & & \\
\hline
\end{tabular}

\section{LITERATURE REVIEW}

Literature Review helps in identifying a gap within the studies done earlier on the topic of research and establishes a framework within which to present and analyse the findings. Literature Review has been done by the researchers to identify the research gap and gain a thorough insight into previous literature.

While going for mergers and acquisitions management expects financial synergy and operating synergy in different manner. But actually are they able to generate that potential synergy or not, is the important issue. Satish Kumar, Lalit Bansal (2008) have
Post liberalization period, 1993, marked its first merger of nationalised banks, when New Bank of India was merged with Punjab National Bank. In 1997 Narasimham Committee II was constituted which stressed on use of merger of banks to reap the benefits of economies of scale, geographical diversification and low costs through branch and staff rationalization, cross-border expansion and growth of market share. Major bank mergers in Indian banking sector are listed in form of Table.
Merged Company

Punjab Co-op Ltd.

Bari Doab Bank Ltd.

Times Bank Ltd.

Bank of Madura

Banaras State Bank Ltd.

Nedungadi Bank Ltd.

IDBI Bank Ltd.

South Gujarat Local Area Bank

Global Trust Bank

United Western Bank

ord Krishna Bank

Sangli Bank

Centurion Bank of Punjab

ING Vyasa Bank

in their work 'The impact of mergers and acquisitions on corporate performance in India' studied the claims made by corporate sector while going for M\&A's to generate synergy. In their study they find out that in many cases of M\&A's the acquiring firms were able to generate synergy in long run that may be in the form of higher cash flow, diversification and cost cuttings etc. In a similar study about'Post-merger corporate performance: an Indian perspective' by Raj Kumar (2009) concluded that the post-merger profitability, assets turnover and solvency of the acquiring 
companies, on an average show no improvement when compared with pre-merger values.

Mergers and acquisitions are considered as corporate events which helps an organization to create synergy and provide sustainable competitive advantage but simultaneous events of these kind have potential to create severe personal trauma and stress which can result in psychological, behavioural, health, performance, and survival problems for both individuals and companies as observed in his paper 'Merger and Acquisition in Banking Industry: $A$ case study of ICICI Bank Ltd' by Dr. K.A. Goyal, Vijay Joshi,(2012)

Appelbaum, Gandell, Yortis, Proper and Jobin (2000) in their study 'Behaviour of Organizational factors and Processes throughout the pre-during-poststages' examined the multiple organizational factors, which directly affect a merger as well as the merger process. They analysed the corporate culture and its effects on employees when two companies merge, organizational change and the reaction of employees to these changes. Further, they studied the issue of stress and other major actions such as communications, corporate culture, change and strategy. Agrawal and Jaffe (2000) observed in their study 'The post-merger performance puzzle', Advances in Mergers and Acquisitions, that while target firm shareholders enjoy short term positive returns, investors of acquirer firms frequently experience share price under performance in the post-acquisition period with negligible overall gain for the shareholders.

Some studies have been conducted in a fashion that performance etc. is classified as pre and post acquisitions. Dr. Anupam Mitra (2015) done a study on 'Indian Banking Industry Performance in Pre and Post Merger and Acquisition' and studied the pre and postmerger financial performance of merged banks with help of financial parameters like gross profit ratio, net profit ratio, operating profit ratio, return on capital employed, and return on equity and debt equity ratios. The findings clearly show that the performance of banks has significantly improved after the merger than before it. Devarajappa S. (2012) studied 'the mergers of HDFC Bank Ltd and Centurion Bank of Punjab Ltd and compared the pre and post-merger financial performance' with the help of same parameters and found that banks have been positively affected by the event of merger.

A study by Beena Saraswathy (2010) on 'Cross Border Mergers and Acquisitions in India: Extent, Nature and Structure' indicates there has been gradual shift in the organic ways (green field mode) of foreign investment into inorganic means of brown field investment. The study also observed that only the world FDI is moving in tandem with the incidence of cross border mergers and acquisitions, but also the service sector mergers and acquisitions are the major force driving world FDI during the study period (1987-2006).

Mergers and Acquisitions activity obviously has long term issues and opportunities for the acquirer and merged entity. Suresh Kumar (2013) studied 'the Impact of merger and acquisitions between Indian Overseas Bank and Bharat Overseas Bank' by comparing their profit per employee, business per employee, investment and advances, interest income, return on assets, NPA's etc. It was observed that merger between the banks has resulted significant improvement in business per employee, investment and advances, interest income .But profit per employee, return on advances and NPA ratio have not recorded significant improvement in the post-merger period.

Rabi Narayan Kar \& Amit Soni (2008) have done 'Strategic Impact analysis for the corporate enterprise in the post liberalisation period'. It was concluded that throughout the period of study (1990-91 to 2000-01) turnover increased after the companies went into mergers and acquisitions. Profit after tax and book values of the companies increased after M\&A's during the period 1994-98 and 1994-99 respectively. After that there was no significant change of M\&A on these variables. It was also observed that M\&A did not had any impact on return on net worth for the period of study.

Smita Meena \& Puspender Kumar (2014) in their paper 'Mergers and Acquisitions Prospects: Indian Banks Study'studies the impact of M\&A's on selected banks (HDFC,SBI \& ICICI Bank) and compares pre and post-merger financial performance of merged banks for period between 2004-2014 with financial parameters like net profit margin, operating profit margin, return on capital employed, return on equity, earning per share, CAR, dividend per share etc. The findings indicates that the pre and post mergers and acquisitions of selected banks in India have no significant changes on profitability ratio. The empirical findings suggest that trend of merger in Indian banking sector has so far been restricted to restructuring of weak and financially distressed banks. It was concluded that merger between distressed and strong banks did not yield any significant efficiency gains to participating banks. However, the forced merger among these banks succeeded in protecting the interest of depositors of weak banks but stakeholders of these banks have not exhibited any gains from mergers.

Praveen Kumari (2014) in their paper 'Mergers and Acquisitions in Indian Banking Sector: A Strategic 
Approach' studied the impact of mergers and acquisitions on few major bank mergers in Indian banking industry (ICICI Bank with Bank of Madura; Centurion Bank with Bank of Punjab; IDBI Bank and United Western Bank Ltd; HDFC and Centurion Bank of Punjab; HSBC, Canara Bank and Oriental Bank of Commerce). It was observed that all the merged entities after mergers are continuously growing than before the merger. There is increase in number of branches and ATM's as well as in deposit amount, their net profit and net worth has also increased after the merger.

\section{ANALYSIS AND FINDIGS \\ (A.1) PRODUCTIVITY ANALYSIS}

Productivity is an essential marker of economic and financial performance of a monetary system. Truth be told, it is an instrument for improving material personal satisfaction and is also fundamental for progress. Profitability is fundamental for progress. It is at the core of financial development and advancement, enhancements in way of life and personal satisfaction.

DEFINITION Productivity refers to the goods and services produced for each unit of capital or labor or both.. In layman language, it is ratio of total output and total input. It is a connection between given yield and the methods used to produce it.

Representatively:-

$$
\text { Productivity }=\frac{\text { TotalOutput }}{\text { Total Input }}
$$

Kopleman has defined productivity as the relationship between physical output of one or more of the associated physical inputs used in production. When single input is used to measure productivity, it is called "factor productivity" and when all factors are combined together for the purpose, it is known as "total factor productivity". 1

\section{CONCEPT OF PRODUCTIVITY IN BANKING}

The idea of productivity as applied in manufacturing sector can't be applied in banking sector as it is an service segment. In banking field, the different products offered are accounts, drafts, trade settlements, cheques, debit cards, different sorts of advances and so on. Recognizable proof and estimation of yield in banking area is extremely troublesome duty as it is beyond the realm of imagination to expect to change over different administrations offered by banks in physical yield. Be that as it may, banking being a significant monetary action can't bear to dismiss the idea of profitability. Use of the productivity idea turns out to be progressively troublesome in Indian financial part as it is connected with such differentiated viewpoints like operational cost viability, gainfulness, client assistance, sending of credit in country and in reverse districts and so forth yet as the financial division is the reflection of an economy, hence, better working of this segment may prompt by and large development of the economy. Indeed, banks go about as a connection between the individuals who needs to spare and the individuals who need to contribute, so improvement in the efficiency of banking part is especially required for the individuals who need to spare. The idea of productivity investigation in banking area may give deceiving results, if not utilized cautiously. For instance on the off chance that we contrast profitability of PSBs in connection with remote banks, at that point it will be seen that productivity in foreign banks (state benefit per worker) is a lot higher, however this correlation is deluding. Efficiency at national level relies on different components like per capita pay, saving propensities and banking propensities and so on. Notwithstanding it, there are different local elements which influence productivity of players in banking segment. In this way, so as to pass judgment on productivity, it is important to break down each portion, various sizes and region shrewd situating of the banks. In Indian Banking Industry, volume of business turned out to be continuously basic to verify more assets for meeting social goals while keeping up reasonability of operations, business level might be favored as being increasingly illustrative of efficiency.

Firms, businesses and countries can accomplish economical improvement with sustainability through better productivity. Industry is a pushed area for nations as they continued looking for intensity. It might be noticed that banks which have kept up the energy of ceaseless development and productivity demonstrated better proportion of manpower adequacy. Every component has vital sub segments which fill in as building obstructs for productivity. The administration arrangements successfully bolster seriousness on the off chance that they are structures around productivity driven change system, cost collapsing levy structure and innovation and industry vision.

A productivity competitiveness model has been offered by C.B. Rao particularly for Indian environment which encompasses three elements viz.
1. Government Policies,
2. Industry Strategies, and
3. Management Methods 
The degree of productivity direction in different components influences the general degree of competitiveness. The Indian government has propelled a liberalization program to disassemble controls and for moving towards market driven economy. To have the advantages from such measures, productivity driven changes instrument is important, at exactly that point the genuine advantage of progression can be accomplished.

There are number of pointers to quantify the productivity of banking sector. Proportions of profitability at bank or industry level may vary from the pointers of efficiency at branch level. Productivity is influenced by manpower, mechanization and the methods, costing of activities, client service administrations and different outside angles. Following ratio proportions has been utilized to figure productivity of the bank before and after the merger period which are as follows:

\section{Per Employee Indicators (Labour \\ Productivity):}
1. Deposit per employee
2. Advance per employee
3. Business per employee
4. $\quad$ Spread per employee
5. Burden per employee
6. Net profit per employee

Per Branch Indicators (Branch Productivity)
1. Deposits per branch
2. Advance per branch
3. Business per branch
4. Burden per branch
5. Spread per branch
6. Net profit per branch

Table no. 3 - Productivity per employee

\begin{tabular}{|c|r|r|r|r|r|r|}
\hline Year & $\begin{array}{l}\text { Advances per } \\
\text { employee }\end{array}$ & $\begin{array}{l}\text { Deposits per } \\
\text { employee }\end{array}$ & $\begin{array}{l}\text { Business per } \\
\text { employee }\end{array}$ & $\begin{array}{l}\text { spread per } \\
\text { employee }\end{array}$ & $\begin{array}{l}\text { burden per } \\
\text { employee }\end{array}$ & $\begin{array}{l}\text { profit per } \\
\text { employee }\end{array}$ \\
\hline 2019 & 8.497026 & 11.31725 & 19.81428 & 0.343433 & -0.34615 & -0.002715 \\
\hline 2018 & 7.327954 & 10.24971 & 17.57766 & 0.283493 & -0.30829 & -0.024797 \\
\hline 2017 & 7.496783 & 9.757029 & 17.25381 & 0.295179 & -0.24515 & 0.0500274 \\
\hline Av. Post & 7.773921 & 10.44133 & 18.21525 & 0.307368 & -0.29986 & 0.0075053 \\
\hline 2016 & 7.045862 & 8.331235 & 15.3771 & 0.273814 & -0.22591 & 0.0478998 \\
\hline 2015 & 6.096598 & 7.394523 & 13.49112 & 0.257999 & -0.19656 & 0.0614411 \\
\hline Av. Pre. & 6.57123 & 7.862879 & 14.43411 & 0.265907 & -0.21124 & 0.0546704 \\
\hline
\end{tabular}

Advances per employee; Deposits per employee ,Business per employee, spread per employee, Burden per employee, profit per employee before and after the merger of the SBI bank has been depicted by the above table. The Advances per employee and Deposits per employee were 6.096598 and 7.394523 in 2015 and 7.045862 and 8.331235 in 2016 respectively. After the Merger, Advances per employee and Deposits per employee of SBI Bank were 7.496783and 9.757029 in 2017,7.327954 and 10.24971in $2018,8.497026$ and 11.31725 in 2019 respectively. It is clear from the table that the Advances given by SBI per employee and deposits of the SBI per employee had increased after its Merger. Before the Merger Business per employee of SBI bank was 13.49112 in 2015 and 15.3771 in 2016 which rose to 17.25381 in 2017 . During 2018, business per branch had risen to17.57766 during 2018 and 19.81428 during 2019. The spread and burden per employee were 0.257999 and $(-0.19656)$ in 2015, 0.273814 and $(-0.22591)$ in 2016. After the merger, the spread and burden per employee were 0.295179 and ($0.24515)$ in $2017,0.283493$ and $(-0.30829)$ in $2018,0.343433$ and $(-0.34615)$ in 2019 respectively. Profits per employee was 0.0614411 during 2015, which declined to 0.0478998 during 2016. Post-Merger , an increment is seen in the profits of SBI per branch initially during 2017(0.0500274), which became negative afterwards during 2018 (-0.0247971) and $2019(-0.0027145)$.It is evident from the above tables that, there has been an increase in the Average per branch after the Merger period.; Average Advances per branch and Average Deposits per branch was 6.57123and 7.862879 before the merger which rose to 7.773921 and 10.44133 respectively post- merger. There is increase in the Average business per branch post-merger to 18.21525 from 14.43411 pre- merger. 
The Average increase per branch during the Pre and Post-Merger Period in spread as 0.265907 and 0.307368 ; burden (-0.21121) and (-0.29986),profits 0.0546704 and 0.0075053

Table no. 4 - Productivity per Branch

\begin{tabular}{|c|c|c|c|c|c|c|}
\hline \multicolumn{1}{|c|}{ Year } & $\begin{array}{l}\text { Advances } \\
\text { per branch }\end{array}$ & $\begin{array}{l}\text { Deposits } \\
\text { per branch }\end{array}$ & $\begin{array}{l}\text { Business } \\
\text { per Branch }\end{array}$ & $\begin{array}{l}\text { Spread per } \\
\text { Branch }\end{array}$ & $\begin{array}{l}\text { Burden per } \\
\text { branch }\end{array}$ & $\begin{array}{l}\text { profit per } \\
\text { branch }\end{array}$ \\
\hline 2019 & 99.31 & 132.2756 & 231.5885 & 4.014033 & -4.04576 & -0.03173 \\
\hline 2018 & 86.32 & 120.74343 & 207.06806 & 3.339597 & -3.63171 & -0.29211 \\
\hline 2017 & 91.5 & 119.08861 & 210.58997 & 3.60278 & -2.99217 & 0.610606 \\
\hline $\begin{array}{l}\text { Post-Merger } \\
\text { Average }\end{array}$ & 92.38 & 124.04 & 216.42 & 3.652137 & -3.55655 & 0.095588 \\
\hline 2016 & 87.21 & 103.1174 & 190.32548 & 3.38905 & -2.79618 & 0.592865 \\
\hline 2015 & 79.6 & 96.540333 & 176.13541 & 3.368349 & -2.5662 & 0.802153 \\
\hline Pre-Merger Average & 83.405 & 99.83 & 183.23 & 3.3787 & -2.68119 & 0.697509 \\
\hline
\end{tabular}

Advances per branch; Deposits per branch ,Business per branch, spread per branch, Burden per branch, profit per branch before and after the merger of the SBI bank has been depicted by the above table. The Advances per branch and Deposits per branch were 79.6 and 96.540333 in 2015 and 87.21 and 103.1174 in 2016 respectively. After the Merger, Advances per branch and Deposits per branch of SBI Bank were 91.5 and 119.08861 in $2017,86.32$ and 120.74343 in 2018 ,99.31 and 132.2756 in 2019 respectively. It is clear from the table that the Advances given by SBI and deposits of the SBI had increased after its Merger. Before the Merger Business per branch of SBI bank was 176.13541 in 2015 and 190.32548 in 2016 which rose to 210.58997 in 2017. During 2018, business per branch had fallen to 207.06806 which further rose to 231.5885 during 2019. The spread and burden per branch were 3.368349 and $(-2.56662)$ in 2015 and 3.38905 and $(-2.79618)$ in 2016.After the merger, the spread and burden per branch were 3.60278 and ($2.99217)$ in $2017,3.339597$ and $(-3.63171)$ in $2018,4.014033$ and $(-4.04576)$ in 2019 respectively. Profits per branch was 0.802153 during 2015, which declined to 0.592865 during 2016. Post-Merger, an increment is seen in the profits of SBI per branch initially during 2017(0.610606), which became negative afterwards during $2018 \quad(-0.29211)$ and 2019(0.03173 ).It is evident from the above tables that, there has been an increase in the Average per branch after the Merger period.; Average Advances per branch and Average Deposits per branch was 83.405 and 99.83 before the merger which rose to 92.38 and 124.04 respectively post merger. There is increase in the Average business per branch post-merger to 216.42 from 183.23 pre- merger. The Average increase per branch during the Pre and Post Merger Period in spread as 3.3787and 3.652137 ; burden (-2.68119) and (3.55655 ),profits 0.697509 and 0.095588 .

\section{PROFITABILITY ANALYSIS PROFITABILITY}

Profitability is rate expressing profit as a percentage of total assets or sales or any other variable to represent the relationship. In fact, there may be various dimensions of profitability analysis. A large number of ratios can be used in order to measure the bank's profitability as-

1. Interest income to working fund ratio

2. Interest expense to working fund

3. Spread to working fund

4. Noninterest income to working fund ratio

5. Other operating expense to working fund ratio

6. Net profit to working fund ratio

7. Interest income to total income ratio

8. Interest expense to total expense ratio

Be that as it may, profitability of banks cannot be viably evaluated using all these ratios as working fund used as denominator in these ratios is total assets and the total assets are accounting (balance sheet) figures, that depends on historical costs and so are not reasonable marker for evaluating current performance of the bank. So as to have an appropriate indicator for assessing the current performance of banks we have used volume of business (advances + deposits) in the denominator. It is only like utilize gross profit ratio (gross profit $\div$ sales) as a substitute for return on total assets (net profit $\div$ total assets).

The following ratios have been used for measuring the profitability of the bank after and before its merger which is as follows:

1. Interest earned ratio $(\mathrm{R})=$ Interest 
earned $\div$ Volume of business

2 . Interest paid ratio $(\mathrm{P})=$ Interest paid

$\div$ Volume of business

3. Non-interest income ratio $(\mathrm{N})=$ Non-Interest income $\div$ Volume of business

4. Other operating expense ratio $(\mathrm{O})=$ Other operating expense $\div$ Volume of business

Where,

a) Non-interest income $=$ Total income Interest income

b) Other operating expense $=$ Total expense - Interest expense
From the above listed ratios following two equations are derived-

1. Spread ratio $(\mathrm{S})=$ Interest earned ratio - Interest paid ratio $(\mathrm{R}-\mathrm{P})$

2. Burden ratio $(\mathrm{B})=$ Other operating expense ratio - Non-interest income ratio (O $-\mathrm{N})$

The profitability is derived from above listed two equations as-

Profitability ratio $(\mathrm{P})=$ Spread ratio Burden ratio $(\mathrm{S}-\mathrm{B})$

Table No. 5- Interest earned, Interest Paid and Spread Ratio

\begin{tabular}{|c|c|c|c|}
\hline Year & Interest Earned Ratio & Interest paid Ratio & Spread \\
\hline 2019 & 4.76 & 3.03 & 1.73 \\
\hline 2018 & 4.75 & 3.14 & 1.61 \\
\hline 2017 & 4.85 & 3.14 & 1.71 \\
\hline Post-Average & 4.79 & 3.10 & 1.69 \\
\hline 2016 & 5.12 & 3.34 & 1.78 \\
\hline 2015 & 5.30 & 3.39 & 1.91 \\
\hline Pre-Average & 5.21 & 3.37 & 1.85 \\
\hline
\end{tabular}

The above table 2 discloses the spread before and after the merger period,which is the difference between Interest Earned Ratio and Interest paid Ratio .In pre -Merger period i.e.2015, the Interest Earned Ratio was 5.30,which further decreased to 5.12 during 2016.After the Merger of SBI, the Interest Earned Ratio was 4.85 in the initial year i.e. 2017 which declined to 4.75 during 2018 and 4.76 during 2019.The average Interest Earned Ratio before Merger was 5.21 which showed a downturn i.e. 4.79 after the merger period . In pre -Merger period i.e. 2015 , the Interest Paid Ratio was 3.39,which further declined to 3.34 during 2016.After the Merger of SBI, the Interest Paid Ratio declined to 3.14 in the initial year i.e. 2017 and remained to 3.14 during 2018 and continued to decline and reached 3.03 during 2019. The average Interest Paid Ratio before Merger was 3.37 which showed a downturn i.e. 3.10 after the Merger period. The spread was 1.91 during 2015 which further decreased to 1.78 during 2016. On an average the spread was 1.85 before the Merger .After the Merger, there was an up-down trend in spread. In 2017 Spread was 1.71, which decreased to 1.61 during 2018 and increased to 1.73 during 2019. The average spread in pre and post-merger period was 1.85 and 1.69 respectively.

Table No.6- Non-interest income, other operating income and burden ratio

\begin{tabular}{|c|c|c|c|}
\hline Year & $\begin{array}{c}\text { Non-interest income } \\
\text { Ratio }\end{array}$ & $\begin{array}{c}\text { Other operating expense } \\
\text { ratio }\end{array}$ & Burden \\
\hline 2019 & 0.69 & 2.44 & -1.75 \\
\hline 2018 & 0.96 & 2.71 & -1.75 \\
\hline 2017 & 0.98 & 2.4 & -1.42 \\
\hline Post-Average & 0.88 & 2.52 & -1.69 \\
\hline 2016 & 0.88 & 2.35 & -1.47 \\
\hline 2015 & 0.78 & 2.24 & -1.46 \\
\hline Pre-Average & 0.83 & 2.3 & -1.47 \\
\hline
\end{tabular}


The above table 3 reveals the burden before and after the merger period, which is the difference between Non-Interest Income Ratio and other operating expense Ratio .In pre -Merger period i.e. 2015 , the Non Interest Income Ratio was 0.78 , which further inclined to 0.88 during 2016.After the Merger of SBI, the NonInterest Income Ratio was 0.98 in the initial year i.e. 2017 which declined to 0.96 during 2018 and 0.69 during 2019.The average Non-Interest Income Ratio before Merger was 0.83 which showed an Upturn i.e. 0.98 after the merger period. In pre - Merger period i.e.2015, the other operating expense Ratio was 2.24, which further inclined to 2.35 during 2016.After the Merger of SBI, the other operating expense Ratio was 2.4 during 2017 which inclined to 2.71 during 2018 and declined afterwards and reached 2.44 during 2019.The average other operating expense Ratio before Merger was 2.3 which showed an Upturn i.e. 2.52 after the Merger period. The burden remained negative before and after the merger of the bank. It was (-1.46) during 2015 and (-1.47) during 2016. On an average the burden was (-1.47) before the Merger .After the Merger, burden was (-1.42) during 2017 and remained same during 2018 and 2019 i.e. (-1.75.). On an average the post-merger burden was (-1.69).

Table No.7 Profitability of Bank

\begin{tabular}{|c|c|c|c|}
\hline Year & Spread & Burden & Profitability \\
\hline 2019 & 1.73 & -1.75 & 3.48 \\
\hline 2018 & 1.61 & -1.75 & 3.36 \\
\hline 2017 & 1.71 & -1.42 & 3.13 \\
\hline Post-Merger & 1.69 & -1.69 & 3.38 \\
\hline 2016 & 1.78 & -1.47 & 3.25 \\
\hline 2015 & 1.91 & -1.46 & 3.37 \\
\hline Pre-Merger & 1.85 & -1.47 & 3.32 \\
\hline
\end{tabular}

As depicted by the above table 4, the Profit before and after the merger period, which is the difference between Spread and Burden .In pre -Merger period i.e.2015, profit was 3.37 which further decreased to 3.25 during 2016.After the Merger of SBI, the Profit was 3.13 in the initial year i.e. 2017 which increased to 3.36 during 2018 and 3.48 during 2019.The Average Profit before Merger was 3.32 which showed an increase i.e. 3.38 after the merger period .

\section{CONCLUSION}

The study shows there is not much difference in productivity as well as profitability in pre and postmerger period. However the total assets, liabilities and employees as well as branches had increased significantly due to merger. The slight decrease in the productivity indicator both employee wise and branch wise is mainly due to huge increase in branches and employees due to merger. It is interesting to note that profitability as per spread and burden approach shows a positive response. However these conclusions are just based on the observations on the study and it's too early to show exact impact of merger on SBI.

\section{REFERENCES}

1. "Profitability of Banks: A Study conducted" by CRISIL, 2002.

2. Consumer Satisfaction Regarding Home Loans - a comparative study of ICICI bank and SBI bank, Arti
Gaur, International Journal of Information Technology and Knowledge Management, pp 379 to 381, July-December 2009.

3. Productivity and Profitability of Banks in India, $V$. B. Angadi and V. John Devaraj Economic and Political weekly Vol.18, pp-160 to 170, November, 1983.

4. Whether Today's Customers are Satisfied? - A Study with Banks, Ashok Kumar, M. and Rajesh, R. Indian Journal of Marketing, Vol. 39 (9), 2009, September.

5. Performance of Public Sector Commercial Bank - A Case Study of State Bank of Hyderabad, Athma, Prasantha, Abstract of Doctoral Dissertation, Finance India, March 2000.

6. Banking Reforms: Progress and Emerging Issues, Banking Events Update, Vol. 9(6), Anonymous, 2006, June.

7. Paradigm Shift in Banking Sector, Basha, J.V. Southern Economist, Vil. 46 (11), 2007, October.

8. Evaluating Performance of Banks through CAMEL Model: A Case Study of SBI and ICICI", Bodla, B.S. and Verma, R., the ICFAI Journal of Bank Management, Vol.5, No.3, pp.49-63,2006.

9. Managing Profits, Profitability and Productivity in Public Sector Banking, Chopra Kiran ABS Publications, Jalandhar, 1987.

10. Changes in Banking Practices - Current Scenario, Gopakumar, K.C. Southern Economist, Vol. 45(14), November, 2006. 
11. Basel-II and Indian Monetary System: A View, Jagannath, Rekha, Southern Economist, Vol. 45(13),November, 2006.

12. Profitability Analysis: An Overviews," Krishna, Dr. KR Indian Banking Today and Tomorrow, Sept. 1996.

13. Banking Sector Reforms - Experience of PSBs, Malhotra, Meenakshi, Abhigyan, Vol. XVII, No.II

14. Prevention of Frauds in Public Sector Banks, Manoharan, B. Professional Banker, Vol. 7(9),2007.

15. Profitability Trends in Public Sector Banks in India During Post-Reform Period, Medhe, DilipD. Southern Economist, Vol. 45(18), January

16. Banking Reforms and Emerging Issues, Mehla, Sunita et.al Southern Economist, Vol. 49(20), February, 2008.

17. Innovation in Banking in the Reforms Era, Mohanty, Ajay Professional Banker, Vol. 6(4), April, 2006,

18. Corrective Steps Towards Sound Banking, Nitsure, R.R.. Economic and Political Weekly, Vol. XLII(13), 2007

19. Revamping the Banking Sector, Padmanabhan, B.S. Yojana, July, 1998.

20. Performance Snapshot 2003-04 Prasuna, D.G Charted Financial Analyst, Vol.10, No.11, pp.6-13, 2004.

21. Profitability and Productivity in Indian Banking, Ramamoorthy, K.K Chartered Financial Analyst, p.53, February, 1998.

22. Productivity and Competitiveness: A model for developing Economies, Rao, C.B., ASCI Journal of Management, Vol. 23, No.2, March, 1994.

23. Benchmarking in Banking: A CAMEL Approach Towards Sound and Strong Banking, Rao, S. and Datta, L. BECON-98, Canara Bank, pp.156-167, 1998.

24. Bank Profitability: Social Role is no Barrier, Roy, Durgadas, Business Standard, Nov.26, 1986.

25. Strategic Reforms of Banking Sector, Saleem, Dr. Imran, Monthly Commentary, Feb.1995.

26. Indian banking performance and development 2004-05, Satish D., Jutur,S. and Surender,V., Charted Financial Analyst, Special Issue, October, pp.6-30, 2005.

27. Bank Profitability: The Real Issues, Shah, S.G. the Journal of the Indian Institute of Banker, pp. 130144, July-Sep. 1979.

28. Profitability Analysis of Bank Branches (Spread Burden Approach), Sholvapur, M.K,1999.

\section{WEBLIOGRAPHY}

1. www.sbi.org

2. www.rbi.org.in/scripts/publicationsview.aspx?id $=10487$

3. $\quad \underline{w w . r b i . o r g}$

4. $\underline{\text { www.google.com }}$ 